\title{
Composition and cytotoxic activity of essential oils from Xylopia aethiopica (Dunal) A. Rich, Xylopia parviflora (A. Rich) Benth.) and Monodora myristica (Gaertn) growing in Chad and Cameroon
}

\author{
Issakou Bakarnga-Via ${ }^{1,2,4}$, Jean Baptiste Hzounda', Patrick Valere Tsouh Fokou', \\ Lauve Rachel Yamthe Tchokouaha ${ }^{1,5}$, Magali Gary-Bobo ${ }^{4}$, Audrey Gallud ${ }^{4}$, Marcel Garcia ${ }^{4}$, Lucain Walbadet ${ }^{2}$, \\ Youssouf Secka ${ }^{2}$, Pierre Michel Jazet Dongmo ${ }^{3}$, Fabrice Fekam Boyom ${ }^{1 *}$ and Chantal Menut ${ }^{4 *}$
}

\begin{abstract}
Background: Cancer has become a global public health problem and the search for new control measures is urgent. Investigation of plant products such as essential oils from Monodora myristica, Xylopia aethiopica and Xylopia parviflora might lead to new anticancer therapy. In this study, we have investigated the antineoplastic activity of essential oils from fruits of these plants growing in Chad and Cameroon.

Methods: The essential oils obtained by hydrodistillation of fruits of Monodora myristica, Xylopia aethiopica and Xylopia parviflora collected in Chad and Cameroon were analyzed by GC-FID and GC-MS and investigated for their antiproliferative activity against the breast cancer cell line (MCF7).

Results: Overall, monoterpenes were mostly found in the six essential oils. Oils from X. aethiopica and X. parviflora from Chad and Cameroon mainly contain $\beta$-pinene at 24.6\%, 28.2\%, 35.7\% and 32.9\% respectively. Monodora myristica oils from both origins contain mainly a-phellandrene at $52.7 \%$ and $67.1 \%$ respectively. The plant origin did not significantly influence the chemical composition of oils. The six essential oils exerted cytotoxic activity against cancer (MCF-7) and normal cell lines (ARPE-19), with more pronounced effect on neoplastic cells in the majority of cases. The highest selectivity was obtained with the essential oils of X. parviflora from Chad and Cameroon (5.87 and 5.54) which were more cytotoxic against MCF-7 than against normal cell line (ARPE-19) with $I_{50}$ values of $0.155 \mu \mathrm{L} / \mathrm{mL}$ and $0.166 \mu \mathrm{L} / \mathrm{mL}$ respectively.
\end{abstract}

Conclusions: Essential oils from fruits of Monodora myristica, Xylopia aethiopica and Xylopia parviflora have shown acceptable antineoplastic potency, and might be investigated further in this regard.

Keywords: Essential oils, Cytotoxicity, MCF-7 cells, ARPE-19 cells, Monoterpene, Sesquiterpene

\section{Background}

Breast cancer is the most frequently diagnosed cancer and the leading cause of cancer death among women, and is the second cause of mortality in sub-Saharan countries $[1,2]$. According to the GLOBOCAN 2010 estimates, the most

\footnotetext{
* Correspondence: fabrice.boyom@fulbrightmail.org;

chantal.menut@univ-montp2.fr

${ }^{1}$ Antimicrobial Agents Unit, Faculty of science, University of Yaoundé I, P.O Box 812, Yaoundé, Cameroon

${ }^{4}$ IBMM, UMR 5247, Equipe Glyco et nanovecteurs pour le ciblage thérapeutique, Université de Montpellier 1, Faculté de Pharmacie, 15 Avenue Charles Flahault, BP 14491, 34093 Montpellier, France

Full list of author information is available at the end of the article
}

common cancer sites in Africa indicate that Cameroon and Chad are highly burdened by breast cancer which is the most frequent cancer in women before the cervical cancer with an incidence rate of 27.9 per 100,000 [3]. These statistics indicate that urgent strategies should be implemented to slowdown the increase of cancer incidence in Africa.

Although there are many therapeutic strategies including chemotherapy, radiation and combination therapies to treat cancer, high systemic toxicity and drug resistance limit the successful outcomes in most cases [4]. Natural products and their synthetic derivatives may be considered as a potential source of novel compounds for 
the treatment of numerous diseases, comprising over $60 \%$ of the approved anticancer drug candidates developed between 1981 and 2002 [5]. Particular attention has been set on the use of essential oils from tropical origin for their cytotoxic activity [6]. Essential oils have shown cytotoxic activity generally without being mutagenic in various organisms $[7,8]$.

The biological properties of aromatic plants such as Annonaceae plants are partially attributed to their essential oils [9]. Aromatic plant such as Xylopia aethiopica are used as spices (fruits) all over central and western Africa, and as a component of herbal medicines for the treatment of skin infections, cough, bronchitis, dysentery, female sterility and fever $[10,11]$. The essential oil of Xylopia aethiopica stem bark was investigated by Boyom et al. [12] and showed activity against the W2 strain of Plasmodium falciparum in culture. Monodora myristica grows naturally in evergreen forests from Liberia to Nigeria and Cameroon, Angola and also Uganda and west Kenya. The fruits and seeds are dried and sold whole or ground to be used in stews, soups, cakes and desserts; they are used as stimulants, stomachic, against headaches, sores and also as insect repellent. In medicine, the bark is used in treatments of stomach-aches, febrile pains, eye diseases and haemorrhoids [13].

Monoterpenes, found in a wide variety of plants including Annonaceae, may be prominent in plant essential oils. In this chemical class, limonene was shown to prevent carcinogen-induced breast cancer at the initiation and the promotion/progression stages. This terpene also causes the complete regression of the majority of advanced rat mammary cancer when added to the diet [14]. In the context of our previous investigations on aromatic plants from tropical areas, the chemical analyses of essential oils obtained by hydrodistillation of fruits of $X$. aethiopica, X. parviflora and $M$. myristica collected in Cameroon showed that all of them were dominated by monoterpenes $[15,16]$. We therefore hypothesized that these essential oils could show potent cytotoxic activity against human breast cancer cells (MCF-7). This led us to carry out further chemical investigations on the essential oils of their fruits collected in Chad and Cameroon and to evaluate their antiproliferative activity by MTT assay.

\section{Methods}

\section{Plant material and extraction procedure}

The fruits of Monodora myristica, Xylopia aethiopica, and Xylopia parviflora (Annonaceae) were collected from Gore (Chad) and Kribi (Cameroon) in March 2012 following the guidelines for biodiversity exploration and preservation in both countries, filed at the National Herbarium of Yaoundé-Cameroon and at the National Center for Research of Chad, where voucher specimens were identified and deposited. Reference identification numbers for voucher specimens at the National Herbarium in Yaoundé are
27690/SFR/CAM, 28725/SFR/Cam, and 42351HNC respectively for Monodora myristica, Xylopia aethiopica, and Xylopia parviflora.

Essential oils were extracted by hydrodistillation using a Clevenger type apparatus. The fruits were hydrodistilled for $5 \mathrm{~h}$, dried over anhydrous sodium sulfate and then preserved at $4^{\circ} \mathrm{C}$ free from the light until used. The yields of extraction were calculated in percentage $(\mathrm{w} / \mathrm{w})$ relative to the weight of the starting plant material.

\section{Chemical analysis}

The determination of the chemical composition of oils was achieved by gas chromatography and by gas chromatography coupled with mass spectrometry.

\section{Gas chromatography analysis}

Gas chromatography (GC) was performed on a Varian CP3380 apparatus equipped with flame ionization detector fitted with a fused silica capillary column $(30 \mathrm{~m} \times 0.25 \mathrm{~mm}$ coated with DB5, film thickness $0.25 \mu \mathrm{m}$ ); temperature program $60-220^{\circ} \mathrm{C}$ at $3^{\circ} \mathrm{C} / \mathrm{min}$, injector temperature $200^{\circ} \mathrm{C}$, detector temperature $220^{\circ} \mathrm{C}$, carrier gas $\mathrm{N}_{2}, 1 \mathrm{~mL} / \mathrm{min} .0 .5 \mu \mathrm{L}$ of essential oil diluted at $10 \%$ in dichloromethane was injected manually. The linear retention indices of the components were determined relatively to the retention times of a series of $n$-alkanes and the percentage compositions were obtained from electronic integration measurements without taking into account relative response factors.

\section{Gas chromatography-mass spectrometry}

GC/MS analyses were performed using a Hewlett-Packard GC 5890 series II equipped with a HP5 (5\%-phenylmethylpolysiloxane) fused silica column $(30 \mathrm{~m} \times 0.25 \mathrm{~mm}$; film thickness $0.25 \mu \mathrm{m}$ ) interfaced with a quadrupole detector (Model 5972) applying the same temperature program as for the GC/FID analyses; injector temperature, $220^{\circ} \mathrm{C}$; MS transfer line temperature, $250^{\circ} \mathrm{C}$; carrier gas, helium at a flow rate of $0.6 \mathrm{~mL} / \mathrm{min}$; injection type, split, 1:10 (1 $\mu \mathrm{L} \quad 10: 100 \mathrm{CH}_{2} \mathrm{Cl}_{2}$ solution); ionization voltage, $70 \mathrm{eV}$; electronmultiplier $1460 \mathrm{eV}$; scan range 35-300 amu; scan rate, $2.96 \mathrm{scan} / \mathrm{s}$. The identification of the constituents was based on comparison of their relative retention indices with either those of authentic samples or with published data in the literature [17] and by matching their mass spectra with those obtained with authentic samples and/or the NBS75K, Wiley 7th NIST $98 \mathrm{EPA} / \mathrm{NIH}$, and FFNSC 2 libraries spectra.

\section{Evaluation of the cytotoxic activities of essential oils on cancer and normal cell lines}

Human breast cancer (MCF-7) and normal epithelial (ARPE-19) cell lines used for cytotoxic activities were purchased from American Type Culture Collection (ATCC, Manassas, VA, USA). They were maintained in Dulbecco's 
Modified Eagle Medium (DMEM) F12 (Life Technologies GIBCO, Grand Island, NY, USA) supplemented with 10\% foetal bovine serum (FBS) (Sigma-Aldrich St. Louis, MO), glutamine, phenol red and $50 \mu \mathrm{g} / \mathrm{mL}$ gentamycine, in humidified atmosphere at $37^{\circ} \mathrm{C}$ and $5 \% \mathrm{CO}_{2}$.

For the cytotoxic study, cells were seeded in 96-well plates at the density of 2,000 cells/well in $200 \mu \mathrm{L}$ of culture medium and allowed to grow for $24 \mathrm{~h}$. Then serially diluted concentrations of essential oils in $10 \%$ absolute ethanol were added to the cells culture at final concentrations ranging from 0.1 to $2 \mu \mathrm{L} / \mathrm{mL}$ and were incubated at $37^{\circ} \mathrm{C}$ for $72 \mathrm{~h}$. Each concentration was tested in triplicate.

The cell viability was measured by using MTT assay as previously described [18]. The assay detects the reduction of MTT [3-(4,5-dimethylthiazolyl)-2,5-diphenyl-tetrazolium bromide] by mitochondrial dehydrogenase to blue formazan product, which reflects the normal functioning of mitochondrial and cell viability [19]. After $72 \mathrm{~h}$ incubation of cells with essential oils, $20 \mu \mathrm{L}$ of MTT reagent at $0.5 \mathrm{mg} / \mathrm{mL}$ was added to each well and incubated for additional $4 \mathrm{~h}$. Then, the medium was removed and $150 \mu \mathrm{L}$ EtOH/DMSO (1:1) was added to MTT precipitates in each well to solubilize the formazan crystals. The plates were read for optical density at $540 \mathrm{~nm}$, using a microplate reader (Multiskan). Percent inhibition of MCF-7 and ARPE-19 cells was calculated using optical density. The value of cell cytotoxicity at $50 \%\left(\mathrm{IC}_{50}\right)$ in the MTT assay was defined as the concentration of test oil resulting in a $50 \%$ reduction of absorbance compared with untreated cells. Selectivity indices were calculated for individual oil from the $\mathrm{IC}_{50}$ values against normal (ARPE-19) and breast cancer (MCF-7) cell lines as SI $=\mathrm{IC}_{50} \mathrm{ARPE}-19 / \mathrm{IC}_{50} \mathrm{MCF}-7$. Safer essential oils were considered as those with $\mathrm{SI}>1.5$.

\section{Results and discussion}

\section{Yields of essential oils extraction}

The hydrodistillation of fruits afforded essential oils with $3.57 \%$ and $4.68 \%$ yields for $X$. aethiopica from Chad and Cameroon respectively. These results are comparable to those previously obtained by Lamaty et al. [15]. The fruits of $X$. parviflora from Chad and Cameroon afforded essential oils with much lower yields $(0.76 \%$ and $0.68 \%$ respectively), close to previous description [16]. Finally, the hydrodistillation of fruits of $M$. myristica collected in Chad and Cameroon gave essential oils with yields of $1.87 \%$ and $2.72 \%$, respectively. These yields are lower than those already observed [15]. These yield variations could be inherent to many factors such as site and period of plant collection.

\section{Chemical composition of the essential oils}

The chemical compositions of the essential oil samples are shown in Table 1. All of them contain a majority of monoterpenes (75.0-94.2\%) with nevertheless important qualitative and quantitative variations according to the botanical species, while no significant difference was observed according to the geographical origin.

The essential oils of $X$. aethiopica from Chad and Cameroon were rich in monoterpene hydrocarbons with contents of $72.4 \%$ and $64.8 \%$ respectively. The main constituents were $\beta$-pinene (24.6.9-28.2\%), sabinene (4.8-14.5\%), $\beta$-phellandrene $(5.8-10.4 \%)$ and $\gamma$ terpinene (4.9-5.7\%). Oxygeneted monoterpenes were significantly represented $(13.3-21.6 \%)$ dominated by terpinen-4-ol (10.0-15.1\%). These results corroborate those obtained by Lamaty et al. $[15,16]$ as well as those reported more recently by Keita et al. [20] and Noudjou et al. [21]. Of note, the stem bark oil previously investigated by Boyom et al. [12] was qualitatively distinct with $\beta$-pinene (10.07\%), myrtenol (6.4\%), spathulenol (6.33\%), and $\gamma$-ylangene (5.32\%) as major constituents.

The essential oils obtained by hydrodistillation ot fruits of $X$. parviflora collected in Chad and Cameroon were also dominated by pinenes ( 43.7 to 46.8 ), but they differ from the samples of $X$. aethiopica oils by a minor content of sabinene (3.0 to $3.2 \%)$ and $\beta$-phellandrene (0.6 to $0.7 \%$ ), while (E)- $\beta$-ocimene accounted for 5.4 to $8.0 \%$ of the volatile extracts. They were also characterized by high content of sesquiterpenes (23.1 to $23.6 \%$ ), dominated by cadinene and muurolane skeletons (i. e. $\delta$-cadinene, $\alpha$-and $\gamma$ muurolenes, trans-muurola-4(14),5-diene, epi- $\alpha$-cadinol, $\alpha$-muurolol) representing $10.2 \%$ and $12.1 \%$ of the whole oils from Chad and Cameroon respectively. These results corroborate those obtained by Lamaty et al. [16] from essential oil of fruits of X. parviflora collected in the Bayagam area (Cameroon).

The essential oils obtained from fruits of $M$. myristica collected in Chad and Cameroon predominantly consisted of monoterpene hydrocarbons $(87.8 \%$ and $82.3 \%$ respectively), the oxygenated derivatives representing only $6.4 \%$ and $3.4 \%$ of the whole oils. Both samples contained $\alpha$-phellandrene as major compound with $52.7 \%$ and $67.1 \%$ respectively. The sample from Chad is characterized by a high content of limonene (14.9\%); on the other hand the oil from Cameroon differs by more than $10 \%$ of sesquiterpenes (mainly cadinane derivatives). This result is comparable to that of Lamaty et al. [15] who found $48.8 \%$ of $\alpha$-phellandrene in a sample collected in Yaoundé area (Cameroon).

\section{Cell cytotoxicity of essential oils}

The cytotoxic activity of all essential oils was evaluated on human breast cancer (MCF-7) and normal epithelial (ARPE-19) cell lines using the MTT assay based on cell viability. Cells were exposed to the oils at concentrations ranging from 0.1 to $2 \mu \mathrm{L} / \mathrm{mL}$.

The cytotoxic effects of the essential oils on human normal or cancer cell lines are shown in Figure 1. The 
Table 1 Relative percentages of constituents of essential oils from fruits of $X$. aethiopica, X. parviflora and M. myristica

\begin{tabular}{|c|c|c|c|c|c|c|c|c|}
\hline \multirow{2}{*}{\multicolumn{2}{|c|}{$\begin{array}{l}\text { Components } \\
\text { LRI }\end{array}$}} & \multicolumn{2}{|c|}{$X$. aethiopica } & \multicolumn{2}{|c|}{ X. parviflora } & \multicolumn{2}{|c|}{ M. myristica } & \multirow[t]{2}{*}{ Identification methods } \\
\hline & & Chad & CMR & Chad & CMR & Chad & CMR & \\
\hline \multicolumn{2}{|c|}{ Monoterpenes } & 85.7 & 86.4 & 75.9 & 75.0 & 94.2 & 88.4 & \\
\hline \multicolumn{2}{|c|}{ Monoterpenes hydrocarbons } & 72.4 & 64.8 & 58.5 & 60.7 & 87.8 & 82.3 & \\
\hline 926 & a-thujene & 1.3 & 1.0 & - & - & 2.4 & 1.4 & LRI. GCMS \\
\hline 931 & a-pinene & 8.3 & 10.8 & 11.1 & 10.8 & 6.7 & 4.2 & LRI. GCMS \\
\hline 971 & sabinene & 14.5 & 4.8 & 3.2 & 3.0 & 0.3 & 0.1 & LRI. GCMS \\
\hline 977 & $\beta$-pinene & 24.6 & 28.2 & 35.7 & 32.9 & 0.5 & 0.3 & LRI. GCMS \\
\hline 985 & myrcene & 0.3 & 0.3 & - & - & 5.1 & 3.8 & LRI. GCMS \\
\hline 1002 & a-phellandrene & 0.6 & 0.5 & - & - & 52.7 & 67.1 & LRI. GCMS \\
\hline 1014 & a-terpinene & 2.8 & 3.4 & - & - & 0.2 & 0.1 & LRI. GCMS \\
\hline 1022 & p-cymene & 0.6 & 0.8 & 1.2 & 2.8 & $\operatorname{tr}$ & $\operatorname{tr}$ & LRI. GCMS \\
\hline 1028 & limonene & 1.7 & 0.4 & 0.3 & 0.5 & 14.9 & 1.8 & LRI. GCMS \\
\hline 1029 & $\beta$-phellandrene & 10.4 & 5.8 & 0.6 & 0.7 & 4.2 & 3.0 & LRI. GCMS \\
\hline 1030 & 1,8-cineole & - & - & 1.0 & 2.0 & - & - & LRI. GCMS \\
\hline 1032 & (Z)- $\beta$-ocimene & 1.1 & 1.3 & $\operatorname{tr}$ & $\operatorname{Tr}$ & 0.3 & 0.3 & LRI. GCMS \\
\hline 1042 & (E)- $\beta$-ocimene & 0.2 & 1.3 & 5.4 & 8.0 & 0.1 & 0.2 & LRI. GCMS \\
\hline 1055 & $\gamma$-terpinene & 4.9 & 5.7 & - & - & 0.4 & $\operatorname{tr}$ & LRI. GCMS \\
\hline 1085 & terpinolene & 1.1 & 1.5 & - & - & $\operatorname{tr}$ & $\operatorname{tr}$ & LRI. GCMS \\
\hline \multicolumn{2}{|c|}{ Oxygenated monoterpenes } & 13.3 & 21.6 & 17.4 & 14.3 & 6.4 & 3.4 & \\
\hline 1095 & trans-sabinene hydrate & 0.4 & 0.3 & - & - & - & - & LRI. GCMS \\
\hline 1096 & linalool & - & - & 0.6 & 0.7 & 2.4 & 2.1 & LRI. GCMS \\
\hline 1119 & cis-p-menth-2-en-1-ol & 0.3 & 0.3 & - & - & 0.2 & $\operatorname{tr}$ & LRI. GCMS \\
\hline 1136 & trans-p-menth-2-en-1-ol & - & - & - & - & 0.1 & $\operatorname{tr}$ & LRI. GCMS \\
\hline 1138 & trans-pinocarveol & 0.6 & 0.9 & 4.0 & 3.2 & - & - & LRI. GCMS \\
\hline 1144 & trans-verbenol & - & - & 0.7 & 0.4 & - & - & LRI. GCMS \\
\hline 1163 & pinocarvone & - & - & 1.2 & 0.7 & - & - & LRI. GCMS \\
\hline 1166 & borneol & - & - & 0.6 & 0.6 & - & - & LRI. GCMS \\
\hline 1178 & terpinen-4-ol & 10.0 & 15.1 & 0.8 & 0.7 & - & - & LRI. GCMS \\
\hline 1187 & p-cymen-8-ol & - & - & 1.0 & 0.7 & - & - & LRI. GCMS \\
\hline 1189 & a-terpineol & 1.6 & 3.6 & 1.4 & 1.7 & 0.5 & 0.6 & LRI. GCMS \\
\hline 1193 & myrtenol & - & - & 6.5 & 5.2 & - & - & LRI. GCMS \\
\hline 1195 & mytenal & 0.4 & 1.4 & - & - & - & - & LRI. GCMS \\
\hline 1195 & trans-thujen-3-ol & - & - & - & - & 2.8 & 0.7 & LRI. GCMS \\
\hline 1234 & cis-thujen-3-ol & - & - & - & - & 0.1 & - & LRI. GCMS \\
\hline 1285 & bornyl acetate & - & - & 0.6 & 0.4 & - & - & LRI. GCMS \\
\hline 1295 & thymol & - & - & - & - & 0.3 & - & LRI. GCMS \\
\hline \multicolumn{2}{|c|}{ Sesquiterpenes } & 12.6 & 11.6 & 23.1 & 23.6 & 3.3 & 11.2 & \\
\hline \multicolumn{2}{|c|}{ Sesquiterpene hydrocarbons } & 12.0 & 10.2 & 10.3 & 10.3 & 1.9 & 6.7 & \\
\hline 1337 & S-elemene & 0.9 & 0.8 & $\operatorname{tr}$ & $\operatorname{Tr}$ & - & - & LRI. GCMS \\
\hline 1340 & a-cubebene & 0.2 & 0.4 & $\operatorname{tr}$ & $\operatorname{Tr}$ & - & - & LRI. GCMS \\
\hline 1369 & a-ylangene & 0.8 & 0.4 & 0.4 & 0.6 & - & - & LRI. GCMS \\
\hline 1377 & a-copaene & tr & $\operatorname{tr}$ & 0.4 & 0.5 & - & - & LRI. GCMS \\
\hline 1391 & $\beta$-elemene & 0.4 & 0.5 & 0.6 & 0.4 & 0.1 & 0.1 & LRI. GCMS \\
\hline
\end{tabular}


Table 1 Relative percentages of constituents of essential oils from fruits of $X$. aethiopica, X. parviflora and M. myristica (Continued)

\begin{tabular}{|c|c|c|c|c|c|c|c|c|}
\hline 1422 & $\beta$-caryophyllene & 0.3 & $\operatorname{tr}$ & $\operatorname{tr}$ & $\operatorname{Tr}$ & 0.2 & 0.3 & LRI. GCMS \\
\hline 1435 & $\beta$-copaene & - & - & 1.4 & 1.1 & - & - & \\
\hline 1450 & a-humulene & 0.2 & 0.8 & - & - & 0.1 & 0.3 & LRI. GCMS \\
\hline 1478 & $\gamma$-muurolene & 0.4 & 1.1 & 0.3 & 0.5 & 0.1 & 0.4 & LRI. GCMS \\
\hline 1485 & germacrene D & 7.2 & 5.1 & 1.3 & 2.0 & - & - & LRI. GCMS \\
\hline 1493 & trans-muurola-4(14),5-diène & - & - & 1.6 & 1.8 & 0.4 & 0.3 & LRI. GCMS \\
\hline 1499 & bicyclogermacrene & 0.5 & 0.3 & - & - & 0.1 & - & LRI. GCMS \\
\hline 1502 & a-muurolene & - & - & 0.7 & 0.8 & 0.1 & 0.4 & LRI. GCMS \\
\hline 1515 & Y-cadinene & - & - & - & - & 0.1 & 1.7 & LRI. GCMS \\
\hline 1523 & $\delta$-cadinene & 0.7 & 0.3 & 3.6 & 3.7 & 0.7 & 3.2 & LRI. GCMS \\
\hline 1561 & germacrene B & 0.4 & 0.5 & - & - & - & - & LRI. GCMS \\
\hline \multicolumn{2}{|c|}{ Oxygenated sesquiterpenes } & 0.6 & 1.4 & 12.8 & 13.3 & 1.4 & 4.5 & \\
\hline 1518 & cubebol & - & - & 1.5 & 1.7 & - & - & LRI. GCMS \\
\hline 1548 & elemol & - & - & 1.5 & 2.0 & - & - & LRI. GCMS \\
\hline 1578 & germacrene D-4-ol & - & - & - & - & 0.5 & 1.3 & LRI. GCMS \\
\hline 1589 & caryophyllene oxide & - & - & 3.0 & 2.0 & - & - & LRI. GCMS \\
\hline 1630 & $M=220$ & 0.3 & 1.1 & 1.0 & 0.8 & - & - & GCMS \\
\hline 1642 & epi-a-cadinol & - & - & 2.0 & 2.4 & 0.1 & 0.9 & LRI. GCMS \\
\hline 1647 & a-muurolol & - & - & 2.0 & 2.9 & - & - & LRI. GCMS \\
\hline 1652 & a-cadinol & 0.3 & 0.3 & - & - & 0.1 & 0.9 & LRI. GCMS \\
\hline 1686 & germacra-4(15),5, 10(14)-triene-1- a-ol & - & - & 1.8 & 1.5 & - & - & LRI. GCMS \\
\hline 1696 & shyobunol & - & - & - & - & 0.7 & 0.3 & LRI. GCMS \\
\hline 1698 & (2Z,6Z)-farnesol & - & - & - & - & - & 1.1 & LRI. GCMS \\
\hline \multicolumn{2}{|c|}{ Total identified } & 98.3 & 98.0 & 99.0 & 98.6 & 97.5 & 96.9 & \\
\hline \multicolumn{2}{|c|}{ EO extraction yields (\%) } & 3.57 & 4.8 & 0.7 & 0.68 & 1.87 & 2.7 & \\
\hline
\end{tabular}

$\mathrm{CMR}=$ Cameroon; LRI = linear retention indices on a HP-5 column; - = not found, $\operatorname{tr}=$ trace (relative concentration $<0.1 \%$ ); EO = essential oil.

$\mathrm{IC}_{50}$ values and the selectivity indices were given in each case. The essential oils from fruits of $X$. aethiopica, $X$. parviflora and $M$. myristica produced a highly significant $(\mathrm{p}<0.005)$ decrease in living cancer cells $(\mathrm{MCF}-7)$ after $72 \mathrm{~h}$ of incubation. Importantly, the effects on normal epithelial cells (ARPE-19) were mainly less pronounced.

The fruit essential oils of $X$. parviflora from Chad and Cameroon were the most active on the cancer MCF-7 cells with $\mathrm{IC}_{50}$ values of 0.155 and $0.166 \mu \mathrm{L} / \mathrm{mL}$ while on normal ARPE-19 cells they showed $\mathrm{IC}_{50}$ values of 0.910 and $0.920 \mu \mathrm{L} / \mathrm{mL}$, expressing a selective cytotoxic effect $(\mathrm{SI}=5.871$ and 5.542 respectively). These oils showed the best profile as potential sources for cancer therapy development. On the other hand, X. aethiopica oils from Chad and Cameroon were less cytotoxic and they exhibited different activity according to their origin. Only the essential oil of $X$. aethiopica from Chad showed a higher cytotoxic effect on cancer cells than on normal cells with a $\mathrm{SI}=$ 3.794. The same essential oil coming from Cameroon presented comparable effects on neoplastic and normal cells.
Finally, M. myristica essential oil appeared also to be more cytotoxic on cancer cells than on normal cells with a SI $=3.476$ for the oil from Chad and SI $=4.777$ for the oil from Cameroon.

Many reports have been published on the cytotoxic effect of different Annonaceae plant extracts on human cancer and non-cancer cell lines, but few is known about the cytotoxic effect of the essential oils of $X$. aethiopica, X. parviflora, and M. myristica. Choumessi et al. [22] and Kuete et al. [23] reported the antiproliferative activity of hydroethanolic extract of $X$. aethiopica against cancer cell lines with $\mathrm{IC}_{50}$ values of $12 \mu \mathrm{g} / \mathrm{mL}$ against $\mathrm{HCT} 116$ colon cancer cells, $7.5 \mu \mathrm{g} / \mathrm{mL}$ and $>25 \mu \mathrm{g} / \mathrm{mL}$ against U937 and KG1a leukemia cells, $6.86 \mu \mathrm{g} / \mathrm{mL}$ and $3.91 \mu \mathrm{g} / \mathrm{mL}$ against MiaPaCa-2 and CCRF-CEM cells. Adaramoye et al. [24] also showed the antiproliferative effect of $X$. aethiopica extract on human cervical cancer cells. On the other hand, it was reported that components such as terpinen-4-ol and $\alpha$-cadinol which are found in all the tested essential oils presented activity against breast, colon, gastric, lung, 


\section{A X.parviflora-Chad}

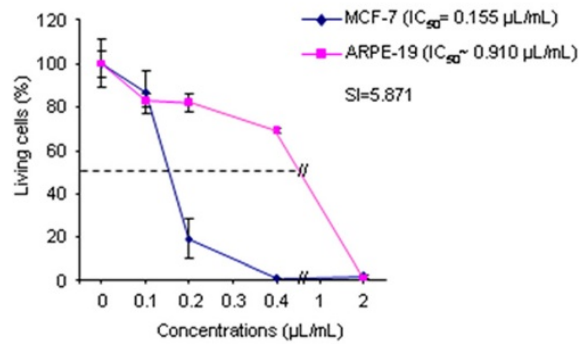

C
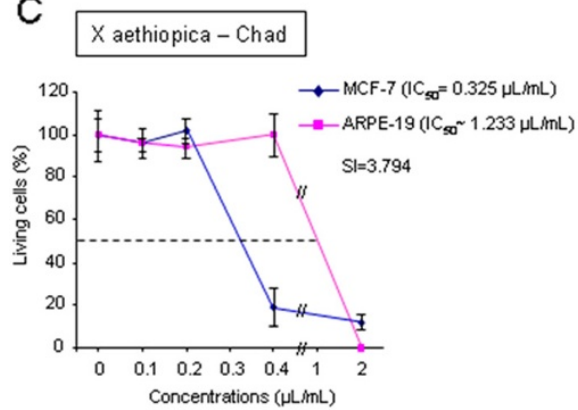

E
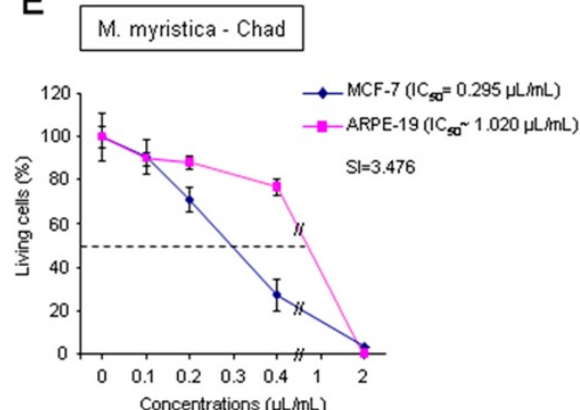

B X parviflora-Cameroon

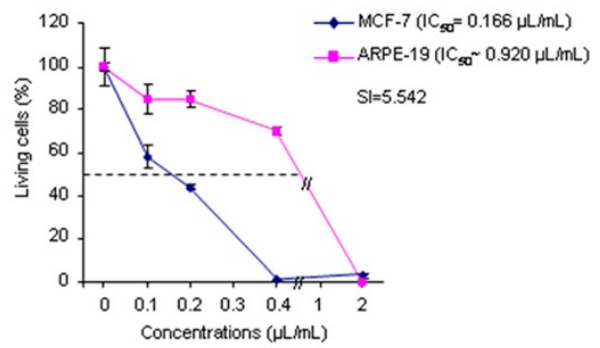

D aethiopica - Cameroon

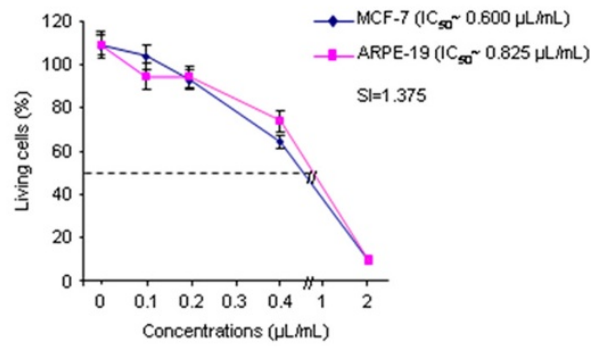

$\mathrm{F}$ M. myristica - Cameroon

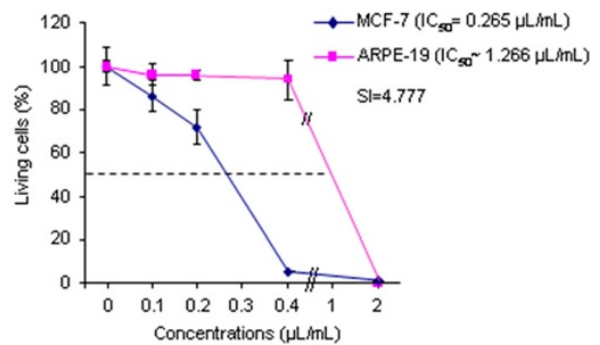

Figure 1 Dose-dependent cytotoxic effect of the essential oils of X. parviflora from Chad (A) and Cameroon (B), X. aethiopica from Chad (C) and Cameroon (D) and M. myristica from Chad (E) and Cameroon (F). Human breast cancer (MCF-7) and normal (ARPE-19) cell lines were incubated $72 \mathrm{~h}$ with increasing doses of essential oils from 0.1 to $2 \mu \mathrm{L} / \mathrm{mL}$. After treatment, cytotoxicity was measured by MTT assay as described in Material and Methods. Values are means \pm standard deviations of three independent experiments.

ovarian and laryngeal cancer cell lines [25]. In addition, $\beta$ pinene which is one of the most naturally occurring monoterpene found in the oil of Xylopia species, has shown a significant cytotoxic activity against breast cancer and epidermal skin cancer cell lines [26].

Besides, it has been shown that limonene can improve the cytotoxic activity of essential oils against neoplasms through induction of apoptosis and phase 1 and phase 2 carcinogen metabolizing enzymes (cytochrome P450) that metabolize carcinogens to less toxic forms and prevent the interaction of chemical carcinogens with DNA [27]. Though, the M. myristica oil from Chad which was rich in limonene (14.9\%) did not present the best cytoxic efficiency against MCF-7 cells. The best results obtained for the two X. parviflora oils and for the M. myristica sample from Cameroon, could be due to their content of oxygenated sesquiterpenes.

Finally, the significant cytotoxic activity against MCF-7 cells of $X$. parviflora fruits oils could be explained by the presence of caryophyllene oxide which was not present in the other samples. Sibanda [28] previously demonstrated the antiproliferative effect of caryophyllene oxide against SK-MEL-28, MDA-MB-231, Hs 578 T, and 5637 cancer cell lines. They also found that caryophyllene oxide $(100 \mu \mathrm{g} / \mathrm{mL})$ was cytotoxic on breast cancer (MCF-7) and prostate cancer (PC-3) cells with $89.67 \%$ and $96.75 \%$ of cell death respectively.

Definitely, the high monoterpenic content in $X$. aethiopica and M. myristica oils and the occurrence of potent anticancer compounds such as limonene in these extracts 
did not influence their cytotoxicity against MCF-7 cells, contrary to the findings of Miller et al. [29]. In the contrary, the essential oils from $X$. parviflora lacking this component showed the best activity against the cancer cells. This is an indication that anticancer activity might be rather related to a sum of interactions between oils components [30], or to the occurrence of different or trace elements.

\section{Conclusion}

The results from this work showed that essential oils of $X$. aethiopica, X. parviflora and M. myristica fruits from Chad and Cameroon were qualitatively comparable, within the same botanical species with modest quantitative variations. Their higher cytotoxic effect on breast cancer cells (MCF-7) than on normal cells (ARPE-19 cells) highlighted their potential as source of eventual therapy against human breast cancer. Further detailed investigations are required to light on specific components that elicit cytotoxic activity and identify their mechanisms of action.

\begin{abstract}
Abbreviations
GC/MS: Gas chromatography-mass spectrometry; MTT: [3-(4,5dimethylthiazolyl)-2,5-diphenyl-tetrazolium bromide]; GC: Gas chromatography; CMR: Cameroon; LRI: Linear retention indices on a HP-5 column; - = not found; Tr: Trace (concentration < 0.1\%); EO: Essential oils.
\end{abstract}

\section{Competing interests}

The authors declare that they have no competing interests.

\section{Authors' contributions}

FFB, PMJD, IB-V, JBHF, VPFT, LRYT, MGB, and YS designed the study and participated in plant selection and collection, spectral analyses and in the drafting and correction of the manuscript. IB-V, MG, LW, AG, and CM performed GC, GC/SM analyses of the essential oils and carried out the cytotoxicity assay. They also contributed to data analysis and critically revised the manuscript. IB-V, JBHF, VPFT, and LRYT extracted the essential oils. All the authors read and approved the final manuscript version.

\section{Acknowledgements}

This work received funding from the University of Adam Barka of Abeche (Chad) to Bakarnga-Via Issakou. We are mostly grateful to Mr Victor Nana from Cameroon National Herbarium and Mr Secka Youssouf from National Center Research of Chad for their assistance with the collection and identification of plant materials.

\section{Author details}

${ }^{1}$ Antimicrobial Agents Unit, Faculty of science, University of Yaoundé I, P.O Box 812, Yaoundé, Cameroon. ${ }^{2}$ Department of Biology, Faculty of Science, University of Adam Barka-Abeche, P.O. Box 1173, Abeche, Chad. ${ }^{3}$ Faculty of Science, University of Douala, P.O. Box 24157, Douala, Cameroon. ${ }^{4}$ IBMM, UMR 5247, Equipe Glyco et nanovecteurs pour le ciblage thérapeutique, Université de Montpellier 1, Faculté de Pharmacie, 15 Avenue Charles Flahault, BP 14491, 34093 Montpellier, France. ${ }^{5}$ Institute of Medical Research and Medicinal Plants Studies (IMPM), Yaoundé, Cameroon.

Received: 3 February 2014 Accepted: 27 March 2014

Published: 4 April 2014

\section{References}

1. Jemal A, Bray F, Center MM, Ferlay J, Ward E, Forman D: Global cancer statistics. CA Cancer J Clin 2011, 61:69-90.

2. Ahmedin J, Rebecca S, Jiaquan X, Elizabeth W: Cancer Statistics. CA Cancer J Clin 2001, 60(Suppl 5):277-300.
3. GLOBOCAN: International Agency for Research on Cancer. France: Lyon; 2010:16.

4. Buchholz M, Gress TM: Molecular changes in pancreatic cancer. Expert Rev Anticancer Ther 2009, 9:1487-1497.

5. Nobili S, Lippi D, Witort E, Donnini M, Bausi L, Mini E, Capaccioli S: Natural compounds for cancer treatment and prevention. Pharmacol Res 2009, 59(Suppl 6):365-378.

6. Unlu M, Ergene E, Vardar UG, Zeytinoglu HS, Vural N: Composition, antimicrobial activity and in vitro cytotoxicity of essential oil from Cinnamomum zeylanicum Blume (Lauraceae). Food Chem Toxicol 2010, 48:3274-3280

7. Prashar A, Locke IC, Evans CS: Cytotoxicity of lavender oil and its major components to human skin cells. Cell Prolif 2004, 37:221-229.

8. De Sousa AC, Alviano DS, Blank AF, Alves PB, Alviano CS, Gattass CR: Melissa officinalis L. essential oil: antitumoral and antioxidant activities. J Pharm Pharmacol 2004, 56:677-681.

9. Aminimoghadamfarouj N, Nematollahi A, Wiart C: Annonaceae: bio-resource for tomorrow's drug discovery. J Asian Nat Prod Res 2011, 13(Suppl 5):465-476.

10. Faulkner DF, Lebby D, Waterman PG: Chemical studies in the Annonaceae. Part 19. Further diterpenes from the stem bark of Xylopia aethiopica. Planta Med 1985, 4:354-355.

11. Ghana Herbal Pharmacopoeia: Policy Research and Strategic Planning Institute (PORSPI). In The Advent Press. Accra; 1992:150-152.

12. Boyom FF, Ngouana V, Amvam Zollo PH, Menut C, Bessiere JM, Gut J, Rosenthal PJ: Composition and antiplasmodial activities of essential oils from some Cameroonian medicinal plants. Phytochemistry 2003, 64:1269-1275.

13. Weiss EA: Spice Crops. Oxon: CABI Publishing; 2002:102-103.

14. Gould MN: Prevention and therapy of mammary cancer by monoterpenes. J Cell Biochem Suppl 1995, 22:139-144.

15. Lamaty G, Menut C, Bessiere JM, Amvam Zollo PH, Boyom FF: Aromatic plants of Tropical Central Africa. I. Volatile components of two Annonaceae from Cameroon: Xylopia aethiopica (Dunal) A. Richard and Monodora myristica (Gaertn). Flavour Frag J 1987, 2:91-94.

16. Lamaty G, Menut C, Bessiere JM, Amvam Zollo PH, Boyom FF: The essential oil of Xylopia parviflora (A. Rich) Benth. from Cameroon. J Essent Oil Res 1989, 1:247-248.

17. Adams RP: Identification of essential oils by gas chromatography quadrupole mass spectrometry. Carol Stream: Allured Publishing Corporation; 2007.

18. Gary-Bobo M, Brevet D, Benkirane-Jessel N, Raehm L, Maillard P, Garcia M, Durand JO: Hyaluronic acid-functionalized mesoporous silica nanoparticles for efficient photodynamic therapy of cancer cells. Photodiagnosis Photodyn Ther 2012, 9(Suppl 3):256-260.

19. Lau CBS, Ho CY, Kim CF, Leung KN, Fung KP, Tse TF, Chan HHL, Chow MSS: Cytotoxic activities of Coriolus versicolor (Yunzhi) extract on human leukemia and lymphoma cells by induction of apoptosis. Life Sci 2004 75:797-808.

20. Keita B, Sidibe L, Figueredo G, Chalchat JC: Chemical composition of the essential oil of Xylopia aethiopica (Dunal) A Rich from Mali. J Essent Oil Res 2003, 15(Suppl 4):267-269.

21. Noudjou F, Kouninki H, Hance T, Haubruge E, Ngamo LST, Maponmestsem PM, Ngassoum M, Malaisse F, Marlier M, Lognay G: Composition of Xylopia aethiopica (Dunal) A. Rich essential oils from Cameroon and identification of a minor diterpene: ent-13-epi manoyl oxide. Biotechnol. Agron Soc Environ 2007, 11(3):193-199.

22. Choumessi AT, Danel M, Chassaing S, Truchet I, Penlap VP, Pieme AC, Tazoacha AT, Ducommun B, Valette A: Characterization of the antiproliferative activity of Xylopia aethiopica. Cell Div 2012, 7:1-8.

23. Kuete V, Krusche B, Youns M, Voukeng I, Fankam AG, Tankeo S, Lacmata S, Efferth T: Cytotoxicity of some Cameroonian spices and selected medicinal plant extracts. J Ethnopharmacol 2011, 134:803-812.

24. Adaramoye OA, Sarkar J, Singh N, Meena S, Changkija B, Yadav PP, Kanojiya S, Sinha S: Antiproliferative action of Xylopia aethiopica fruit extract on human cervical cancer cells. Phytother Res 2011, 25(Suppl 10):1558-1563.

25. Ren Z, Gould MN: Modulation of small G protein isoprenylation by anticancer monoterpenes in situ mammary gland epithelial cells. Carcinogenesis 1998, 19:827-832.

26. Helen MPA, Vargheese TA, Kumari JJ, Abiramy MR, Sajina N, Sree JS: Phytochemical analysis and anticancer activity of essential oil from Myristica fragrans. Int J Curr Pharma Rev Res 2012, 2(Suppl 4):188-198.

27. Sun J: D-Limonene: Safety and Clinical Application. Alternative Med Rev 2007, 12:259-264. 
28. Sibanda S, Chigwada G, Poole M, Gwebu ET, Noletto JA, Schmidt JM, Reac Al, Setzer WN: Composition and bioactivity of the leaf essential oil of Heteropyxis dehniae from Zimbabwe. J Ethnopharmacol 2004, 92:107-111.

29. Miller JA, Lang JE, Ley M, Nagle R, Hsu CH, Thompson PA, Cordova C, Waer A, Chow HH: Human breast tissue disposition and bioactivity of limonene in women with early-stage breast cancer. Cancer Prev Res 2013, 6:577-584.

30. Bakkali F, Averbeck S, Averbeck D, Idaomar M: Biological effects of essential oils. Food Chem Toxicol 2008, 46:446-475.

doi:10.1186/1472-6882-14-125

Cite this article as: Bakarnga-Via et al.: Composition and cytotoxic activity of essential oils from Xylopia aethiopica (Dunal) A. Rich, Xylopia parviflora (A. Rich) Benth.) and Monodora myristica (Gaertn) growing in Chad and Cameroon. BMC Complementary and Alternative Medicine 2014 14:125.

\section{Submit your next manuscript to BioMed Central and take full advantage of:}

- Convenient online submission

- Thorough peer review

- No space constraints or color figure charges

- Immediate publication on acceptance

- Inclusion in PubMed, CAS, Scopus and Google Scholar

- Research which is freely available for redistribution 